\title{
Zniewolone partykuły. Wyrażenia funkcyjne jako narzędzia w semantyce składnikowej
}

Słowa klucze: wyrażenia funkcyjne, czasowniki, wiedza, akt mowy, metodologia, ustalanie komponentów znaczenia

\section{Wstęp}

Termin „wyrażenia funkcyjne” zaczerpnęłam od Macieja Grochowskiego. Pomysł skonfrontowania jednostek języka należących do różnych części mowy, lecz posiadających te same nietrywialnie elementy znaczenia również przejęłam od M. Grochowskiego (1986: 121). Wykorzystała go w swojej pracy także Magdalena Danielewiczowa (np. 2002: 138).

Mówiąc o zniewoleniu pewnej klasy wyrażeń, mam na myśli taką sytuację, gdy zostają one wykorzystane do tego, aby przy ich użyciu ustalać pewne komponenty semantyczne innych wyrażeń lub sprawdzać, czy komponenty te są elementem ich znaczenia. Za narzędzia posłużą mi wyrażenia: jako$b y$, podobno, rzekomo i wedtug $X$ - $a$. Zestawiam je w różnych kontekstach z wybranymi czasownikami, aby zobaczyć, czy i w jaki sposób wzajemnie na siebie oddziałują, modyfikując przy tym (lub nie) swoje znaczenie. Punktem wyjścia jest hipoteza, że istnieje pewna regularność związana z dystrybucją wspomnianych wyrażeń funkcyjnych oraz pokrewnych znaczeniowo 
czasowników. I że ta regularność powiązana jest z określonymi komponentami znaczenia tych czasowników. Hipotezę tę staram się zweryfikować, zestawiając najpierw omawiane wyrażenia z takimi czasownikami, jak mówić, $\dot{z} e$ p, poinformować, że p, wiedzieć, że p i insynuować, $\dot{z} e p^{l}$. Gdyby wyniki procedury weryfikacyjnej okazały się pozytywne, wówczas - analizując właściwości innych czasowników, semantycznie pokrewnych - można by ustalić (lub zweryfikować), czy dany komponent pojawia się również w ich znaczeniu. W tym celu wystarczyłoby sprawdzić ewentualną kookurencję tych czasowników i wymienionych wyrażeń funkcyjnych. Dlatego kolejnym krokiem jest zestawienie tych wyrażeń z czasownikami, które łączą w swym znaczeniu nacechowanie epistemiczne z informacją o akcie mowy: ktoś twierdzi, że $p$; ktoś stwierdził, że p; ktoś utrzymuje, że p, i obserwacja rezultatów uzyskanych w wyniku tej operacji ${ }^{2}$. Ostatnim etapem prowadzonych przeze mnie rozważań jest zastosowanie wspomnianych narzędzi w odniesieniu do jednostek epistemicznych, zawierających w swym znaczeniu także komponent zdający sprawę z gotowości nadawcy do powiedzenia czegoś: uważać, że $p$, myśleć, że p oraz sqdzić, że p, opisanych przez M. Danielewiczową (2002).

Zdaję sobie sprawę $\mathrm{z}$ tego, że pomysł zastosowania wyrażeń funkcyjnych jako narzędzi w analizie właściwości semantycznych czasowników sam w sobie może wydawać się dość kontrowersyjny. Po pierwsze, adekwatny opis tych wyrażeń funkcyjnych, które znajdują się w kręgu mojego zainteresowania, jest niezwykle trudny ze względu na ich szczególną pozycję w strukturze zdania. Nie są one uwikłane w tradycyjnie rozumiane związki składniowe $^{3}$, nie podlegają też tak pojmowanym oddziaływaniom składniowym, nie mają składniowych właściwości konotacyjnych. $\mathrm{O}$ wiele łatwiej jest

${ }^{1}$ Czasowniki te zostały już wcześniej opisane przez innych uczonych (m.in. A. Bogusławskiego, B. Bojar, J. Reszkę, A. Wierzbicką i Z. Zaron), mają pewne szczególne własności semantyczne. Mianowicie obrazują trzy różne kategorie epistemiczne: wiedzę, $\dot{z}$ jest tak a tak (dla czasownika wiedzieć, że p i poinformować, że p), wiedzę, że nie jest tak a tak (dla czasownika insynuować, że p) oraz niewiedzę, czy jest tak a tak (mówić, $\dot{z} e p$ ). Więcej informacji na ten temat znajduje się w dalszej części artykułu.

2 Wybrałam te czasowniki, ponieważ pierwsze dwa przez słowniki wymieniane są jako para aspektowa (twierdzić : stwierdzić), natomiast trzeci (utrzymywać) jako synonim twierdzić. Ich szczegółową analizę prezentuję w M. Stępień (2010).

3 Wyjąwszy wyrażenie według X-a, o którym pisał M. Grochowski (1997: 93). Kiedy w dalszych częściach artykułu będę posługiwała się tym wyrażeniem, należy rozumieć, że czynię to, interpretując jego znaczenie tak, jak M. Grochowski we wspomnianej pracy. 
określić, czym owe wyrażenia nie są, niż scharakteryzować je pozytywnie w sposób mniej ogólnikowy. Trudno oprzeć się pokusie, aby powiedzieć, że są to wyrażenia metatekstowe ${ }^{4}$. Na potrzeby prowadzonych rozważań posłużę się tym pojęciem w sposób operacyjny5: definiując je negatywnie. Mówiąc „wyrażenie metatekstowe”, mam na myśli takie wyrażenie, które nie realizuje miejsca w zdaniu w rozumieniu składni tradycyjnej, nie ma składniowych właściwości konotacyjnych i nie jest także uwikłane w oddziaływania akomodacyjne. $\mathrm{Z}$ poczynionych ustaleń wynikałoby zatem, że nie mówimy tu z pewnością o spójnikach ${ }^{6}$, co jest szczególnie istotnym zastrzeżeniem w odniesieniu do wyrażenia jakoby. Za Bogusławskim przyjmuje, że jednostka ktoś wie o czymś, że $p$ jest niedefiniowalna oraz że właśnie wiedza, iż jest tak a tak to stan epistemicznie neutralny (por. Bogusławski 1994, 2007). Również jednostki języka wyodrębniam, odwołując się do metody wypracowanej przez tego uczonego. Posługując się pojęciem ,nacechowanie epistemiczne”, czynię to w takim znaczeniu jak w M. Stępień (2010).

Statusem i właściwościami leksemów jakoby, podobno i rzekomo zajmowali się A. Wierzbicka (1969) i B. Wiemer (2006). O statusie jednostki jakoby pisały również A. Łojasiewicz (1992) i J. Wajszczuk (1997).

W ostatnim czasie na temat rzekomo i jakoby wypowiedział się także A. Bogusławski (2009: 41-42), stwierdzając, że są to partykuły zawsze nieakcentowane (nie inaczej niż korekcyjnie). Ponadto jednostka rzekomo jest powszechnie nadużywana i wstawiana tam, gdzie nadawca powinien raczej zastosować inne słowo, np. jakoby czy mieć. Jak napisał uczony: „W użyciu poza ramą powiedzial, że nasze partykuły tworzą wespół z innymi wyrażeniami, ewentualnie „domyślnymi” (por. np. Rzekomo grzmi., gdzie domyślne jest miejsce scharakteryzowane za pomocą wyrazu grzmi), temat konceptual-

${ }^{4}$ Pojęciu metatekstu oraz zakresowi jego odniesienia poświęcono w ostatnim czasie wiele prac. Toczą się też wokół tego zagadnienia liczne dyskusje. Jednak szczegółowe ich przedstawienie nie jest przedmiotem niniejszego artykułu.

${ }^{5}$ Używam tego pojęcia tak, jak funkcjonuje ono w języku ogólnym, a nie w znaczeniu, jakie nadał mu A. Bogusławski.

${ }^{6}$ Mam tu na myśli spójniki w takim rozumieniu, jak ujmuje to m.in. Z. Zaron (2009), tzn. centra zdaniotwórcze z dwustronną konotacją składniową. Miejsce uzupełnień w schemacie konotacyjnym prymarnie mogą zajać zdania lub równoważniki zdań. O tym, ile jednostek języka kryje się za kształtem jakoby, pisałam bardziej szczegółowo m.in. w pracy M. Stępień 2010. Tam też zdaję sprawę z rozważań poświęconych jakoby $\mathrm{w}$ istniejącej literaturze przedmiotu na ten temat. 
ny: 'o [kimś/czymś, do kogo/czego odnosi się mówiacy, używając określonego zwrotu] ktoś mówi, że $i$, które ${ }_{\mathrm{i}}$ jest (i) takie, że nie wiem, czy jest prawdziwe czy fałszywe [dla jakoby]/ takie, że wiem, że jest fałszywe [dla rzekomo], (ii) takie, że ktoś, kto powie, że $i$, powie, że...'."

\section{Wyrażenia jakoby, podobno, rzekomo w połączeniu z czasownikami insynuować, mówić, poinformować, wiedzieć}

Swoje rozważania zacznę od przedstawienia przykładowych kontekstów z partykułami podobno, rzekomo i jakoby:

(1) [...] trzeba tylko znieczulenie dać miejscowe. W sumie to tylko działające na skórę i kość ewentualnie czaszki. Bo mózg podobno nie czuje. $(\mathrm{PWN})$

(2) Trudno uwierzyć, by nie był bardzo złym falsyfikatem mały pejzaż z okolic Paryża, jakoby przez Soutine'a malowany w 1917 roku i zawieszony w przejściu na wystawie u Charpentier [...] (PWN)

(3) Wiele osób publicznych ma pretensje do sędziów, że rzekomo bojkotują ustawę lustracyjną, bo się nie zgłaszają do pracy w sądzie lustracyjnym. (PELCRA)

Jak już wspominałam, punktem wyjścia w moich rozważaniach jest hipoteza, że można odnotować pewną regularność w połączeniach wspomnianych wyrażeń funkcyjnych z czasownikami, których własności zostały już wcześniej opisane przez innych badaczy. I że ta regularność jest powiązana z określonymi komponentami znaczenia tych czasowników. Kluczowym krokiem będzie zatem sprawdzenie, czy owa regularność, konieczna do dalszych poszukiwań, w ogóle ma miejsce. Do tego celu wykorzystam najpierw dwa czasowniki: ktoś poinformowat, że $p$ oraz ktoś mówi, że $p^{7}$. Pierwszy $\mathrm{z}$ nich jest czasownikiem mówienia, odsyłającym do wiedzy nadawcy aktualnego $^{8}$, że $p$, por. sprzeczne zdania oznaczone numerami (4a-b) i (4d-e):

7 O czasowniku mówić/powiedzieć pisał obszernie A. Bogusławski (2005, 2007), zwracając szczególną uwagę na nietożsamość powiedziat:_i powiedziat, że_.

${ }^{8}$ Pod etykietką 'nadawca aktualny' kryje się ten, kto jest odpowiedzialny za całość wypowiedzi. Dla wypowiedzenia Marysia powiedziała, że masz wyrzucić śmieci. byłby to zatem ten, kto je wygłasza, a nie sama Marysia, której słowa są w tym zdaniu jakoś przywołane. 
(4a) *Jacek poinformował, że kupił samochód, ale wcale go nie kupił.

(4b) *Jacek poinformował, że kupił samochód, ale wiem, że go nie kupił.

(4c) Jacek poinformował, że kupił samochód i wiem, że go kupił.

(4d) *Jacek poinformował, że kupił samochód, ale nie wiem, czy go kupił.

(4e) *Jacek poinformował, że kupił samochód, ale tego nie powiedział ${ }^{9}$.

Drugi zaś niefaktywnym czasownikiem mówienia, por. niesprzeczne zdanie (5a):

(5a) Jacek mówi, że nic nie wiedział o całej sprawie, ale nie wiem, czy on o tym nie wiedział.

Rodzimy użytkownik języka polskiego dość swobodnie utworzy zdania, w których obok wymienionych poprzednio czasowników w zdaniu nadrzędnym pojawią się partykuły podobno, rzekomo, jakoby:

(5b) Jacek podobno/rzekomo/jakoby mówi, że nic nie wiedział o całej sprawie.

(5c) Paweł podobno/rzekomo/jakoby poinformował, że nic nie wiedział o całej sprawie.

Tak skonstruowane zdania odsyłają odbiorcę do dwóch aktów mowy:

a) w akcie pierwszym nadawca pierwotny (A, czyli Jacek) powiedział coś (że nic nie wiedziat o całej sprawie),

b) odbiorca tej wypowiedzi (nazwijmy go B) powtórzył to, co usłyszał o innej osobie (niech będzie to ktoś C). Swoją wypowiedź B opatrzył komentarzem odautorskim w postaci czasowników mówić i poinformować. Czasowniki te, jak wcześniej pokazywałam, wskazują jednocześnie na uprzedni (pierwotny) akt mowy oraz (dla mówić) na dystans nadawcy aktualnego w stosunku do przytaczanych słów,

c) ktoś C (nadawca aktualny przytaczający wypowiedź nadawcy B) powtórzył to, co usłyszał od kogoś B, kolejnej osobie (D). Zachował przy tym komentarz nadawcy B (czasowniki mówić i poinformować) i dodał własny komentarz w postaci partykuły podobno, rzekomo lub jakoby. Komentarz ten odnosi się do wiarygodności słów nadawcy B:

9 Poinformować można kogoś o czymś również w formie pisemnej. Przyjmuję jednak założenie, że pismo jest w takim wypadku zawsze wtórne wobec podstawowej formy wypowiedzi: mowy. 
Schemat 1. Wielopoziomowa struktura aktu mowy

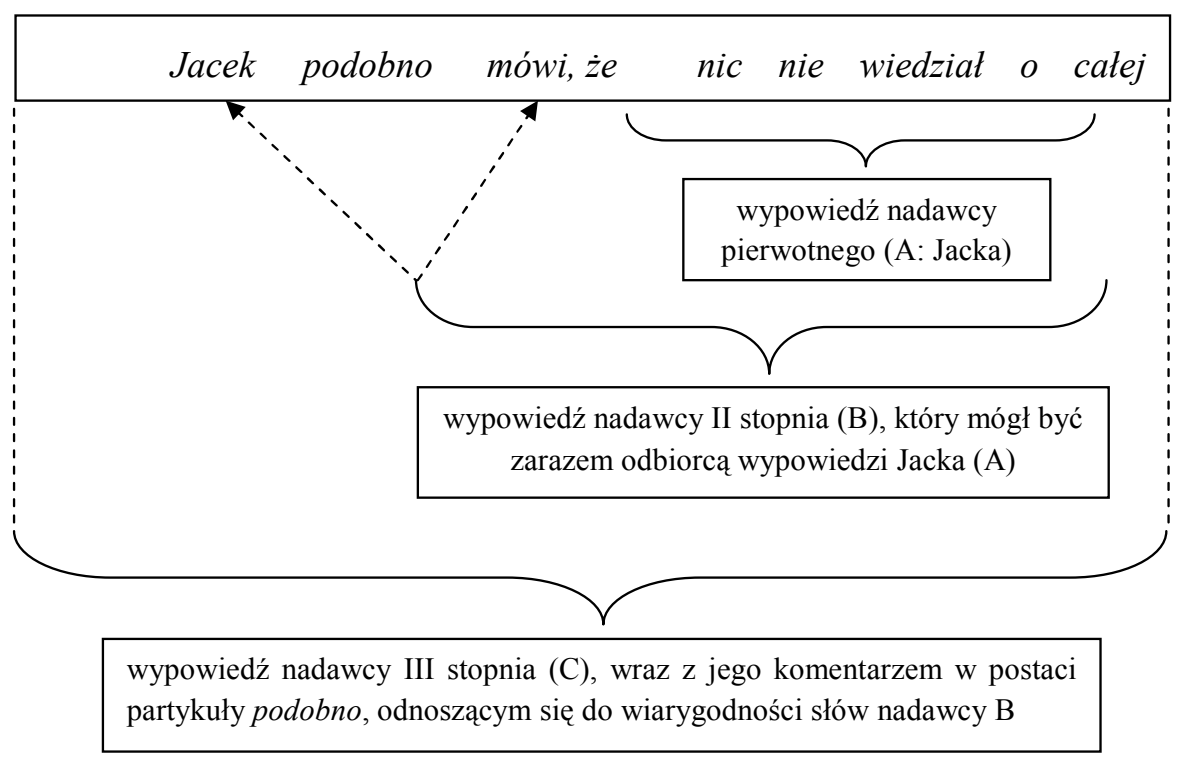

Źródło: opracowanie własne

Tak oto w akcie mowy aktualnym zostały zreferowane dwa akty mowy uprzednie z zaznaczeniem dystansu epistemicznego kolejnych nadawców.

Kolejnym krokiem jest rozważenie sytuacji, gdy partykuły podobno, rzekomo i jakoby zostaną wprowadzone do zdania uzupełniającego konotowanego przez czasowniki ktoś mówi, że p i ktoś poinformowat, że p. Niech za zdanie bazowe posłuży nieco zmodyfikowany przykład z Korpusu referencyjnego języka polskiego (PELCRA):

(6) Mój przyjaciel Archibald Mac Leish mówi ${ }^{10}$, że podobno / jakoby / rzekomo faszyści zniszczyli jakieś biblioteki.

10 Andrzej Bogusławski podczas swoich sobotnich seminariów wielokrotnie zwracał uwagę na fakt, że spośród triady: wie, że p; nie wie, czy p; wie, że nie $p \mathrm{w}$ odniesieniu dla czasownika mówić, że p wykluczona jest tylko ta ostatnia możliwość. Wyniki testu z wyrażeniami jakoby, podobno, rzekomo są zgodne z tym twierdzeniem. Przy użyciu żadnej z tych jednostek nadawca aktualny nie przesądza, że nadawca pierwotny mówi, że $p$ chociaż wie, że nie $p$ (czyli kłamie). 
A oto jego kontrast $\mathrm{z}$ czasownikiem poinformować, że p:

(7) ${ }^{* 11}$ Mój przyjaciel Archibald Mac Leish poinformował, że podobno faszyści zniszczyli jakieś biblioteki.

Jak widać, wprowadzenie partykuły podobno do zdania uzupełniającego konotowanego przez czasownik powoduje sprzeczność. Analogiczny efekt uzyskamy, zastępując jednostkę podobno wyrazami rzekomo czy jakoby. Kontrast ten stanie się jeszcze bardziej widoczny, gdy do zdania nadrzędnego wstawiony zostanie czasownik ktoś wie, że p:

(8) *Mój przyjaciel Archibald Mac Leish wie, że podobno/rzeko mo/jakoby faszyści zniszczyli jakieś biblioteki.

Zatem w zdaniu uzupełniającym konotowanym przez orzeczenie ktoś mówi, że $p$ (inaczej niż w wypadku ktoś wie, że p czy ktoś poinformowat, $\dot{z} e p$ ) może wystąpić każda $\mathrm{z}$ analizowanych partykuł. Powstaje pytanie, czy w tej pozycji składniowej zmieniają się ich właściwości? Jak już wcześniej wspominałam, wyrażenia podobno, rzekomo, jakoby występujące w zdaniu nadrzędnym z czasownikiem ktoś mówi, że p są jednocześnie wykładnikami modalności epistemicznej i jednostkami odsyłającymi do aktu mowy. Służą do hierarchizacji przytaczanych aktów mowy. Jednocześnie dzięki ich zastosowaniu nadawca aktualny uwalnia się od odpowiedzialności za to, co powiedział. Gdy jednak wymienione partykuły pojawiają się w zdaniu uzupełniającym, przestają spełniać funkcję jednostek odsyłających do aktu mowy ${ }^{12}$. Użyte partykuły jakoby, podobno, rzekomo pełnią więc w tym kontekście wyłącznie funkcję wykładników modalności epistemicznej. Do zdania wprowadził je nie nadawca pierwotny, lecz nadawca aktualny. Posłużył się nimi, aby dodatkowo podkreślić swój dystans (dla partykuły podobno) wobec prawdziwości/fałszywości wypowiedzi nadawcy pierwotnego lub też (dla jakoby) powątpiewanie w jej prawdziwość, czy wreszcie otwarte jej negowanie (dla rzekomo).

Aby dopełnić obrazu, należy obejrzeć własności wspomnianych partykuł również $\mathrm{w}$ połączeniu $\mathrm{z}$ czasownikiem przesądzającym fałszywość $p$. Po-

\footnotetext{
11 Nie ma również takich przykładów w NKJP.

12 Więcej na ten temat w M. Stępień 2008.
} 
służę się w tym celu jednostką ktoś insynuuje, że p, korzystając z wniosków, płynących z analiz J. Reszki (2001):

(8b) *Mój przyjaciel Archibald Mac Leish insynuuje, że podobno faszyści zniszczyli jakieś biblioteki.

Nadawca aktualny sięga po wyrażenie insynuować w sytuacji, gdy chce powiedzieć, że nadawca pierwotny mija się z prawdą. Użycie w zdaniu uzupełniającym konotowanym przez to orzeczenie partykuły podobno jest niemożliwe. W wyniku takiej operacji powstaje zdanie sprzeczne. Wprowadzając w miejsce podobno wyrażenia jakoby i rzekomo, uzyskalibyśmy ten sam rezultat ${ }^{13}$. Jest to spójne $\mathrm{z}$ wcześniejszymi rozważaniami prowadzonymi na temat wspomnianych jednostek oraz z uwagami A. Bogusławskiego.

Pozostaje zatem sprawdzić łączliwość wymienionych czasowników z wyrażeniem wedtug $X$ - $a$ :

(8c) *Mój przyjaciel Archibald Mac Leish insynuuje, że według ni ego faszyści zniszczyli jakieś biblioteki.

(8d) Nasza rehabilitantka mówi, że we dług niej wcześniaki powinny być rehabilitowane od samego początku.

(8e) Prowadzący bezpośrednio sprawę prokurator Piotr Skrzypecki p o informował, że według biegłych z WICHiR stan techniczny sprzętu izolacyjnego przechowywanego w kopalniach jest niezadowalający.

(8f) Prowadzący bezpośrednio sprawę prokurator Piotr Skrzypecki p o informował, że według niego ${ }^{14}$ stan techniczny sprzętu izolacyjnego przechowywanego w kopalniach jest niezadowalający.

Zdanie (8c) odrzucam z dwóch powodów: po pierwsze, znaczenie czasownika insynuować wyklucza użycie wyrażenia według $X$ - $a$ w zdaniu uzupełniającym; po drugie, mimo zastosowania wielokierunkowego wyszukiwania kontekstowego nie udało mi się znaleźć tego typu przykładów. Wyrażenie

13 Wyniki prowadzonych przeze mnie rozważań znajdują także osobliwe potwierdzenie w NKJP - mianowicie w postaci braku takich przykładów nawet przy założeniu, że maksymalny dopuszczalny odstęp wynosi 8 segmentów (czyli wyrazów graficznych: od spacji do spacji).

14 Zdanie (8e) przytaczam za NKJP. Przykład (8f) został zmodyfikowany tak, aby zachodziła zgodność między podmiotem zdania nadrzędnego a uzupełnieniem wyrażenia wedtug $X$-a. 
wedtug $X$ - $a$ wskazuje na subiektywność osądu nadawcy pierwotnego: on sam rozumie, że może nie mieć racji i stara się o takiej ewentualności poinformować odbiorcę. Nadawca aktualny przekazuje informację o przekonaniu nadawcy pierwotnego co do subiektywności sądu, dodając wspomniane wyrażenia. Dlatego właśnie pojawienie się tego wyrażenia w zdaniu konotowanym przez czasownik insynuować jest niemożliwe.

Jak widać, dystrybucja podawanych zwykle jako synonimy wyrażeń jakoby, podobno, rzekomo jest częściowo rozłączna. Istnieją czasowniki, które dopuszczają jako określenie w konotowanym zdaniu uzupełniającym tylko jedną lub dwie z wymienionych powyżej partykuł. Istnieją też takie, które nie dopuszczają żadnej z nich i jest to zjawisko regularnie powiązane ze znaczeniem tych jednostek.

\section{Wykorzystanie wyrażeń funkcyjnych do ustalenia komponentów semantycznych czasowników twierdzić, stwierdzić, utrzymywać}

Sprawdźmy zatem, czy właściwość ta może zostać wykorzystana w testach służących ustaleniu czy weryfikacji komponentów semantycznych pozostałych czasowników, które wymieniłam na początku artykułu. Zacznijmy od jednostki ktoś twierdzi, że p:

(9) ${ }^{15}$ Mój przyjaciel Archibald Mac Leish twierdzi, że podobno faszyści zniszczyli jakieś biblioteki.

(9a) Mój przyjaciel Archibald Mac Leish twierd zi, że rzekomo faszyści zniszczyli jakieś biblioteki.

(10) Platforma Obywatelska [...] twierdzi, jakoby podatek liniowy był tym elementem czy instrumentem, który rozwiąże wszystkie nabrzmiałe problemy.

Jak widać, żadne z podanych zdań nie jest sprzeczne. Przy braku tożsamości podmiotów można do zdania uzupełniającego wprowadzić wszystkie trzy wyrażenia. Metanadawca dopuszcza zatem na równych prawach realizację obu możliwości: p i nieprawda, że p. W żadnych okolicznościach nie jest natomiast gotów powiedzieć, że wie, że p. Przy tożsamości podmiotów

15 Przykłady (9) i (10) przytoczyłam w ich oryginalnym kształcie. Pierwszy pochodzi z Referencyjnego Korpusu Języka Polskiego PELCRA, a drugi ze stenogramów przemówień sejmowych. 
w obu zdaniach partykuł podobno, rzekomo, jakoby nie można wprowadzić do zdania uzupełniającego:

(11) *Paweł twierdzi, że jest podobno/rzekomo/jakoby uczciwym człowiekiem.

Powodem tego jest zapewne fakt, że nikt przy zdrowych zmysłach na serio (tzn. nie na prawach gry językowej) nie powie o sobie, że nie wie, czy mówi prawdę.

Jak już wspominałam, inaczej niż w wypadku partykuł podobno, rzekomo czy jakoby, wyrażenie wedtug $X$ - $a$ wskazuje na subiektywność osądu nadawcy pierwotnego. Spróbujmy je zatem wprowadzić jako określenie do zdań uzupełniających konotowanych przez analizowany czasownik:

(12a) Prorocy starotestamentowi twierdzili, że według nich są rzecznikami Boga.

(12b) Prorocy starotestamentowi twierdzili, że według nich Mojżesz był rzecznikiem Boga.

W efekcie ponownie uzyskujemy zdania niesprzeczne. Zatem można wnioskować, że wbrew definicjom słownikowym w znaczeniu czasownika twierdzić nie ma informacji o tym, że nadawca pierwotny jest gotów obstawać przy swoim zdaniu.

Z kolei na podstawie analizy kontekstów z czasownikiem stwierdzićc ${ }^{16}$ można dojść do wniosku, że nadawca całości wypowiedzi używa jednostki stwierdzić, gdy chce dać wyraz swojemu przekonaniu, że wprawdzie on sam nie wie, czy p, czy nie $p$, ale agens, którego słowa zostają przytoczone ${ }^{17}$ w zdaniu uzupełniającym, językowo zachowuje się tak, jak ktoś, kto wie, że p. Właśnie ZACHOWUJE SIE, a nie WIE. Spróbujmy zweryfikować tę hipotezę, używając proponowanych tu narzędzi:

(13) Pan marszałek Borowski stwierdził, jakoby działalność WiN stała z boku nurtu odbudowy kraju. No, przecież odbijano ludzi z ubeckich więzień.

16 Więcej na ten temat w: M. Stępień (2010).

17 Oczywiście zdanie uzupełniające wprowadzane przez że może równie dobrze stanowić przytoczenie, jak i omówienie czy streszczenie tego, co powiedział agens. Używając sformułowania przytoczenie, dokonałam więc pewnego uproszczenia. 
(14) Nazwa została zmieniona na wniosek Związku Piłsudczyków, który stw ierdził, że Węgierko rzekomo służył Sowietom i nie jest godny bycia patronem teatru. Ze zmianą nie zgadzali się m.in. aktorzy teatru, jak też mieszkańcy Białegostoku.

Partykuły rzekomo i jakoby można swobodnie wprowadzić do zdania uzupełniającego. Takiego podstawienia nie sposób jednak dokonać w wypadku wyrażenia podobno, por. budzące wątpliwości przykłady (13a) i (14a):

(13a) ?Pan marszałek Borowski stwierdził, że podobno działalność WiN stała z boku nurtu odbudowy kraju. No, przecież odbijano ludzi $\mathrm{z}$ ubeckich więzień.

(14a) ?Nazwa została zmieniona na wniosek Związku Piłsudczyków, który stwierdził, że Węgierko podobno służył Sowietom i nie jest godny bycia patronem teatru.

Do zdania uzupełniającego można natomiast wprowadzić określenie wedtug $X$ - $a^{18}$, por.:

(13b) Pan marszałek Borowski stwierdził, że według niego działalność WiN stała z boku nurtu odbudowy kraju. No, przecież odbijano ludzi z ubeckich więzień.

(14b) Nazwa została zmieniona na wniosek Związku Piłsudczyków, którego członkowie stwierdzili, że według nich Węgierko służył Sowietom i nie jest godny bycia patronem teatru.

Wydaje się, że odpowiedzialny za ten stan rzeczy jest właśnie komponent epistemiczny czasownika stwierdzić. Nadawca aktualny nie wie, czy p, czy nie p. Natomiast nadawca pierwotny zachowuje się tak, jak ktoś, kto wie, czy $\mathrm{p}$, czy nie $\mathrm{p}^{19}$ i dlatego nadawca aktualny - choć ma wątpliwości - nie jest gotów powiedzieć, że nie p. $Z$ tego samego powodu do zdania uzupełniającego nie można wprowadzić partykuły podobno - gdyż dystans w stosunku

18 Takich kontekstów nie udało mi się też znaleźć ani w korpusach, ani za pomocą wyszukiwarek internetowych.

19 To, że nadawca zachowuje się jak ktoś, kto wie, że p, nie jest równoznaczny z tym, że jest gotów obstawać przy p. Najlepszy sposób powiedzenia, że się coś wie, to zastosowanie zwykłego mówienia pod asercją - mówienia serio, bez dodatkowych leksykalnych 'ozdobników', które zamiast wzmacniać asercję, jedynie ją osłabiają. 
do możliwej prawdziwości lub fałszywości p, wyrażany za pomocą jednostki stwierdzić, nie jest identyczny.

Kolejnym krokiem będzie sprawdzenie, czy przy użyciu proponowanych narzędzi można weryfikować hipotezy o synonimiczności orzeczeń. Za materiał badawczy niech posłużą czasowniki twierdzić, ̇̇e p oraz utrzymywać, $\dot{z} e$ p, przez leksykografów wymieniane często jako para synonimów. Czy w zdaniach uzupełniających przyłączanych obligatoryjnie przez oba orzeczenia mogą wystąpić partykuły jakoby, podobno, rzekomo?

(15a) *Paweł utrzymuje, że podobno został mianowany kierownikiem działu.

(15b) ?Paweł utrzymuje, że jakoby/rzekomo został mianowany kierownikiem działu.

Wydaje się, że przy tożsamości podmiotów w obu zdaniach do propozycji nie sposób wprowadzić żadnej z wymienionych partykuł. Przykłady otrzymane w wyniku takiej operacji są wątpliwe. Nieco inaczej sytuacja wygląda, gdy podmioty w obu zdaniach są różne:

(15c) *Paweł utrzymuje, że podobno Michał został mianowany kierownikiem działu.

(15d) Paweł utrzymuje, że jakoby/rzekomo Michał został mianowany kierownikiem działu.

W tym wypadku do zdania uzupełniającego nie można wprowadzić tylko partykuły podobno, która zaznacza jednakowy dystans nadawcy aktualnego w stosunku do ewentualnej prawdziwości lub fałszywości wypowiedzi nadawcy pierwotnego. Przy użyciu partykuł rzekomo i jakoby nadawca aktualny również nie przesądza wprost prawdziwości czy fałszywości słów nadawcy pierwotnego. Wybierając jednak właśnie je, a nie podobno, informuje potencjalnego odbiorce, iż on sam skłania się ku opinii, że nadawca pierwotny nie ma racji (jakoby) lub nawet jest gotów powiedzieć, że p jest fałszywe (rzekomo). Z przeprowadzonych wcześniej testów wynika, że analogiczną funkcję w zdaniu pełni orzeczenie utrzymywać, że p. Używając jednocześnie wymienionych partykuł i analizowanego orzeczenia, nadawca aktualny podkreśla swój dystans w stosunku do wypowiedzi nadawcy pierwotnego oraz powątpiewanie w prawdziwość jego sądu. Inaczej niż w wypadku, gdy wybiera orzeczenie $t w i e r d z i c ́, \dot{z} e p$. 
Problem z ustaleniem znaczenia czasownika utrzymywać, że $p$ jest jednak bardziej złożony. Redaktor ISJP zauważył, że w tym orzeczeniu zakodowano również przeświadczenie nadawcy pierwotnego o własnej racji. Aby zweryfikować tę hipotezę, można do zdania uzupełniającego przyłączanego przez orzeczenie $u t r z y m y w a c ́, \dot{z} e p$ wprowadzić wyrażenia według $X$-a. Jeśli jest tak, jak twierdzi autor ISJP, przy tożsamości podmiotów w zdaniu nadrzędnym i uzupełniającym operacja taka powinna prowadzić do powstania sprzecznej konstrukcji:

(16) Prorocy starotestamentowi utrzymywali, że są rzecznikami $\mathrm{Boga}^{20}$.

(16a) *Prorocy starotestamentowi utrzymywali, że według nich są rzecznikami Boga.

Zdanie (16a) jest sprzeczne. Dlatego wnioskuję, że hipoteza, iż w orzeczeniu $u t r z y m y w a c ́, \dot{z} e$ p zawarta jest informacja o przeświadczeniu nadawcy pierwotnego co do słuszności i prawdziwości własnej wypowiedzi, okazała się prawdziwa.

\section{Weryfikacja wyników rozważań na materiale czasowników myśleć, sq̨dzić, uważać}

Aby sprawdzić, czy narzędzia te rzeczywiście działają, postanowiłam wykorzystać również analizy przeprowadzone przez o wiele bardziej ode mnie doświadczonych uczonych. Sięgnęłam po jednostki uważać, że p, myśleć, że oraz sqdzić, że p szczegółowo opisane przez M. Danielewiczową (2002). Poniżej przytaczam eksplikacje tych jednostek, zaproponowane przez badaczkę:

a myśli, że p

[T] $a$

[TD] jest taki, że ze względu na to, co wie

[R] jest gotów powiedzieć, że $p$

(Danielewiczowa 2002: 139)

a sqdzi, że p

[T] $a$,

${ }^{20}$ Celowo używam w tym teście identycznego przykładu, jak przy czasowniku twierdzi, że p. W ten sposób wyraźniej widać, że wyniki tego samego testu, przy takim samym kontekście są dla obu jednostek różne. 
[TD] (i) o którym ktoś jest gotów powiedzieć, że nie jest tak, że $a$ wie, że $p$

(ii) który (a) jest gotów powiedzieć, że jego wiedza o sobie samym i o ' $p$ ' jest taka, że może powiedzieć, czy $p, \operatorname{czy} \sim p$,

[R] jest gotów powiedzieć, że $p$.

(Danielewiczowa 2002: 156)

a uważa, że p

$[\mathrm{T}] a$,

[TD] który zrobił coś, takiego, w wyniku czego

jest gotów powiedzieć o ' $p$ ' i o czymś ${ }_{q}$, że jeśli coś

to $p$ i jeśli $\sim \cos _{\mathrm{q}}$, to $\sim p$,

$[R]$ jest gotów powiedzieć, że wie (i) że coś zachodzi,

(ii) że ktoś inny, wiedząc coś, mógłby nie być gotowym powiedzieć, że $p$

(Danielewiczowa 2002: 165)

Następnie do zdań uzupełniających konotowanych przez te jednostki wprowadziłam wyrażenia jakoby, podobno, rzekomo oraz wedtug $x$ - $a$, tak jak w zdaniach z wcześniej obserwowanymi czasownikami. Aby nie wzbudzać podejrzenia, że wyniki testów są oceniane pod kątem zakładanych wyników, każdorazowo sprawdzałam, czy istnieją potwierdzenia dla takich układów w korpusie NKJP. Poniżej przytaczam wyniki moich poszukiwań:

(17) Według radnej Krystyny Dąbrowskiej, takie imprezy jak „Oświęcimskie Juvenalia" czy festiwal hip-hopu zorganizowane przez Stowarzyszenie na rzecz Wspierania Inicjatyw Kulturalnych Ziemi Oświęcimskiej są okazją jedynie do serwowania młodym ludziom piwa. Radna uważa, że rzekomo promowana kultura jest wyłącznie przykrywką dla osiągnięcia maksymalnych zysków.

(18) Trafiają się tacy, którzy z urzędowych ksiąg modlitw publicznych wykreślają pisma Starego Testamentu, uważając, że rzekomo nie odpowiadają one duchowi dzisiejszych czasów i są rzekomo kłopotliwe.

(19) Chcę podkreślić i pójść niejako pod prąd, wbrew przeświadczeniu tych panów posłów i pana senatora, którzy tutaj bagatelizowali opinie środowisk kombatanckich, uważając, że jakoby nie powinny one mieć większego znaczenia w kwestii rozszerzania katalogu podmiotów, którym uprawnienia kombatanckie by przysługiwały. 
(20) Protestujący wcale nie uważają, jakoby ich niezadowolenie było przedwczesne, bo właściwie nie zapadły jeszcze żadne konkretne decyzje w sprawie budowy obiektu handlowego.

(21) Uważasz, że według Jezusa Dekalog nie należy do prawa?

(22) Wielokrotnie sam zauważyłem, że urzędnicy sądzą, jakoby ich znaczenie rosło wtedy, gdy powodują oni trudności i kłopoty. Nie wiedzą być może, że w ten sposób powodują niechęć i niepopularność władz centralnych.

(23) Panie ministrze, z wielu wypowiedzi można było wyciągnąć wniosek, że pewne osoby sądzą, że jakoby w okresie rządów poprzedniej koalicji powstawały pewnego rodzaju zaniedbania itd.

(24) Adwokat sądzi, że o rzekomo nabytym placu mierniczy mógł pisać opierając się na plotkach. Natomiast burmistrz mógł pisać o majątku jako o własności samorządu, będąc przekonanym, że lada chwila dojdzie do sfinalizowania transakcji. Adwokat twierdzi, że wątpliwości mogłaby rozwiać jedynie umowa o sprzedaży Kurhausu.

(25) Czy sądzisz, że skoro według Ciebie ktoś się „,nie liczy”, to to samo sądzić będą owi wszyscy?

(26) Według mnie, i myślę, że również według kolegów z Komisji Gospodarki Narodowej, jeżeli jakiś podmiot jest właścicielem, to wyznacza radę, która ma kształtować określoną politykę.

Zgodnie z przewidywaniami, okazuje się, że w wypadku jednostki ktoś $m y s ́ l i$, ż $p$ niemożliwe jest wprowadzenie do zdania uzupełniającego żadnego z wyrażeń: jakoby, podobno, rzekomo. Do zdania uzupełniającego można natomiast wprowadzić wyrażenie wedtug $X$ - $a$. Test w wypadku generowania sprzeczności wskazuje na komponent 'a nie jest gotów powiedzieć, że nie p'. W rezultacie otrzymujemy zdanie niesprzeczne (26), co jest zgodne z ostatnim elementem znaczenia tej jednostki.

Warto zwrócić uwagę na fakt, że test ten różnicuje również komponent epistemiczny znaczenia jednostek ktoś uważa, że p i ktośsqdzi, że p. W wypadku obu czasowników możliwe jest wprowadzenie do zdania uzupełniającego partykuły jakoby. W wypadku rzekomo sytuacja jest jednak bardziej skomplikowana. W zdaniu uzupełniającym przy czasowniku ktoś uważa, że p możliwe są obie partykuły (por. (18), (21), (22)). Przykład (24) - jakkolwiek niesprzeczny - nie może być uznany za ilustrację demonstrowanego testu. Wyrażenie rzekomo odnosi się bowiem w tym kontekście do określenia 
nabytym, a to $\mathrm{z}$ kolei pochodzi z przekształcenia zdania zwanego przez tradycję przydawkowym (w innych podziałach: zdaniem względnym). Czyli de facto nie jest to wyrażenie operujące na treści zdania uzupełniającego. Takie konteksty pojawiają się również w przykładach z czasownikiem ktoś sqadzi, $\dot{z} e p$, ale w tym wypadku można odnaleźć również zdania niebudzące takich wątpliwości. W odniesieniu do czasownika ktoś uważa, że p takich zdań nie znalazłam i w moim odczuciu nie można ich utworzyć. Ta różnica w dystrybucji wyrażeń funkcyjnych znajduje w mojej opinii potwierdzenie w eksplikacjach obu jednostek.

Czy na podstawie testów z udziałem wyrażeń funkcyjnych można dokonać kompletnej analizy semantycznej innych jednostek języka? Moim zdaniem nie. Odpowiedzi uzyskiwane w ten sposób nie pozwalają precyzyjnie różnicować znaczeń. Testy tworzone za pomocą tych wyrażeń są natomiast dobrym wskaźnikiem do prowadzenia poszukiwań, mogą być również wykorzystywane do weryfikacji wyników, uzyskanych innymi drogami. Pod warunkiem, że używając ich, zachowa się odpowiednią czujność. Partykuły można więc zaprząc do ciężkiej, metodologicznej pracy i w tym sensie je zniewolić.

\section{Bibliografia}

BogusŁawski A., 1988, Jezzyk w stowniku. Desiderata semantyczne do wielkiego stownika polszczyzny, Wrocław: Ossolineum.

Bogusıawski A., 1994, Czy wiedza, że p pociagga za sobą inny stan mentalny?, w: J. Pelc (red.), Znaczenie i prawda, Warszawa: PWN, s. 391-411.

BogusŁawski A., 2005, Do teorii czasownika „powiedzieć”, Polonica XXIV-XXV, s. $139-155$.

Bogustawski A., 2007, A study in the linguistics-philosophy interface, Warszawa: BEL Studio.

BogusŁawski A., 2008, Semantyka, pragmatyka. Leksykografa głos demarkacyjny, Warszawa: Wydawnictwo TAKT.

BogusŁawski A., 2009, Myśli o gwiazdce i regule, Warszawa: BEL Studio.

BogusŁawski A., Danielewiczowa M., 2005, Verba Polona Abscondita. Sonda stownikowa III, Warszawa: Katedra Lingwistyki Formalnej.

Bojar B., 1978, Polskie czasowniki dotyczące procesów informacyjnych. Elementy metainformacji w tekstach języka naturalnego, w: Studia językoznawcze. Streszczenia prac doktorskich 3, Wrocław-Warszawa: Ossolineum, s. 7-45. 
Danielewiczowa M., 2002, Wiedza i niewiedza. Studium polskich czasowników epistemicznych, Warszawa: Katedra Lingwistyki Formalnej.

Grochowski M., 1986, Polskie partykuły. Składnia, semantyka, leksykografia, Prace Instytutu Języka Polskiego PAN, Wrocław: Ossolineum Wrocław.

Grochowski M., 1993, Konwencje semantyczne a definiowanie wyrażén językowych, Biblioteka Myśli Semiotycznej nr 25, Warszawa: Zakład Semiotyki Logicznej Uniwersytetu Warszawskiego.

Grochowski M., 1997, Wyrażenia funkcyjne. Studium leksykograficzne, Kraków: IJP PAN.

ISJP: Bańko M. (red.), 2000, Inny słownik języka polskiego, Warszawa: PWN.

ŁoJASIEwICZ A., 1992, Własności składniowe polskich spójników, Warszawa: Wydawnictwa UW.

ReszKa J., 2001, Predykaty implikujace pojęcie zła w języku polskim, Kraków: Wydawnictwo Naukowe DWN.

STĘPIÉ́ M., 2008, O wzajemnym przenikaniu się ewidencjalności i modalności (na przykładzie wybranych polskich czasowników i wyrażeń funkcyjnych), w: B. Wiemer, V. A. Plungjan (red.), Lexikalische Evidenzialitätsmarker im Slavischen (Wiener Slawistischer Almanach, Sonderband 72), s. 313-333.

STĘPIEŃ M., 2010, Mówienie i prawda. O czasownikowych wykładnikach wiedzy niezweryfikowanej przez mówiqcego, Warszawa: Wydawnictwo Wydziału Polonistyki UW oraz BEL Studio.

Wajszczuk J., 1997, System znaczeń w obszarze spójników polskich. Wprowadzenie do opisu, Warszawa: Katedra Lingwistyki Formalnej UW.

Wiemer B., 2006, Particles, parentheticals, conjunctions and prepositions as evidentiality markers in contemporary Polish, Studies in Polish Linguistics 3, s. 5-67.

WierzBickA A., 1969, Dociekania semantyczne, Wrocław: Zakład Narodowy im. Ossolińskich.

Wierzbicka A., 1971, Metatekst w tekście, w: M. R. Mayenowa (red.), O spójności tekstu, Wrocław: Ossolineum, s. 105-121.

WierzBickA A., 1980, Lingua mentalis. The semantics of natural language, Sydney-Nowy Jork-Londyn etc.: Academic Press.

WierzBickA A., 1987, English speech act verbs. A semantic dictionary, Sydney-San Diego-New York: Academic Press.

ZARON Z., 1980, Ze studiów nad semantyka i składniq czasownika. Polskie czasowniki z uzupetnieniem werbalnym oznaczajace relację osobowa z argumentem zdarzeniowym, Wrocław: Zakład Narodowy im. Ossolińskich.

Zaron Z., 2000, 2001, 2002, Właściwości semantyczne orzeczeń. Preparacje składniowe, Prace Filologiczne, Cz. I, t. XLV, s. 681-691; Cz. II, t. XLVI, s. 673-682; Cz. III, t. XLVII, s. 443-460, Warszawa. 
Zaron Z., 2009, Problemy składni funkcjonalnej, Warszawa: Bel Studio: Wydział Polonistyki UW.

\section{'Enslaved particles'. Functional expressions as tools in the semantics of primitives}

\section{( s u m m a r y)}

The article investigates the possible usage of the functional expressions as appropriate tools in the analysis of the semantic properties of selected verbs. The main aim of the article is to compare the linguistic units belonging to different parts of speech, but having the same, nontrivial, semantic components. 'Enslaving' of an expression is understood here as using it as an analytical tool for identifying semantic components of other linguistic units. Such tools used in this paper include the expressions: jakoby ('purportedly'), podobno ('reportedly'), rzekomo ('allegedly'), wedtug $X$ - $a$ ('according to'), and as the objects undergoing the analysis the following verbs: twierdzić, że $p$ ('to claim'), stwierdzić, że $p$ ('to state'), utrzymywać, że p ('to maintain'), uważać, że $p$ ('to think/consider'), myśleć, że p ('to think'), and sqdzić, że $p$ ('to suppose'). 